Prepared in cooperation with the National Park Service

\title{
Water-Quality Assessment of Part of the Upper Mississippi River Basin, Minnesota and Wisconsin-Organochlorine Compounds in Streambed Sediment and Fish Tissues, 1995-97
}

Water-Resources Investigations Report 00-4213

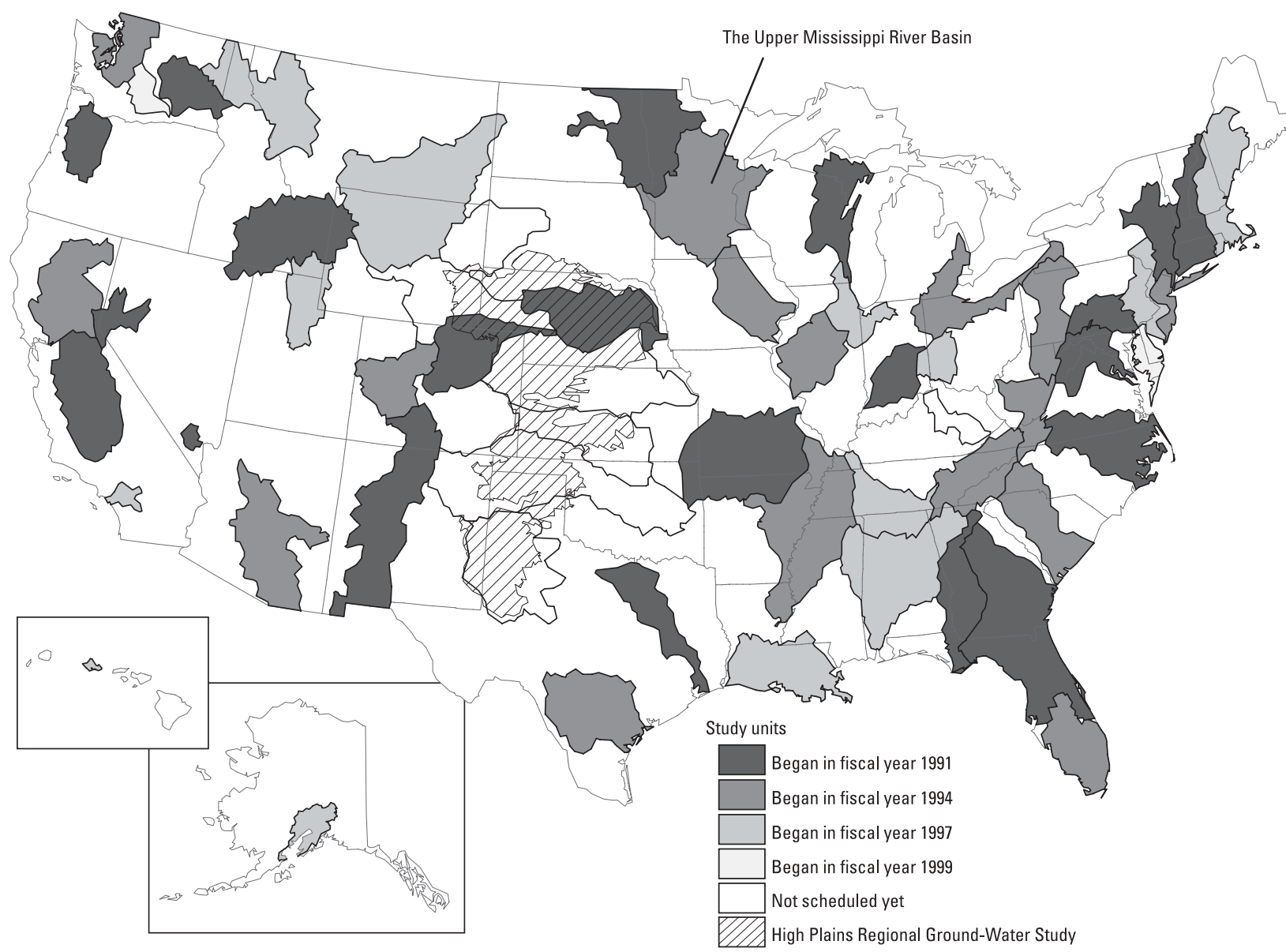

U.S. Department of the Interior

U.S. Geological Survey 


\section{Water-Quality Assessment of Part of the}

Upper Mississippi River Basin, Minnesota and Wisconsin-Organochlorine Compounds in Streambed Sediments and Fish Tissues, 1995-97

By R.P. McNellis, J.D. Fallon, and K.E. Lee

Water-Resources Investigations Report 00-4213 


\title{
U.S. DEPARTMENT OF THE INTERIOR
}

\author{
Gale A. Norton, Secretary
}

\section{U.S. GEOLOGICAL SURVEY}

Charles G. Groat, Director

Use of brand names in this report is for identification purposes only and does not constitute endorsement by the U.S. Geological Survey.

Mound View, Minnesota, 2001

For additional information write to:

U.S. Geological Survey

District Chief

2280 Woodale Drive

Mounds View, MN 55112

Copies of this report can be purchased from:

\section{U.S. Geological Survey}

Branch of Information Services

Box 25286, MS 517

Federal Center

Denver, CO 80225

Information regarding the National Water-Quality Assessment (NAWQA) Program is available on the Internet via the World Wide Web. You may connect to the NAWOA Home Page using the Universal Resource Locator (URL) at:

URL: http://wwwrvares.er.usgs.gov/nawqa/nawqa_home.html

Information about the Upper Mississippi River Basin Project of the NAWQA Program is available at: URL: http://mn.water.usgs.gov/umis/index.html

Water-Resources Investigations Report 00-4213 


\section{Foreword}

The mission of the U.S. Geological Survey (USGS) is to assess the quantity and quality of the earth resources of the Nation and to provide information that will assist resource managers and policy makers at Federal, State, and local levels in making sound decisions. Assessment of water-quality conditions and trends is an important part of this overall mission.

One of the greatest challenges faced by waterresources scientists is acquiring reliable information that will guide the use and protection of the Nation's water resources. That challenge is being addressed by Federal, State, interstate, and local water-resource agencies and by many academic institutions. These organizations are collecting water-quality data for a host of purposes that include: compliance with permits and water-supply standards; development of remediation plans for a specific contamination problem; operational decisions on industrial, wastewater, or water-supply facilities; and research on factors that affect water quality. An additional need for water-quality information is to provide a basis on which regional and national-level policy decisions can be based. Wise decisions must be based on sound information. As a society we need to know whether certain types of water-quality problems are isolated or ubiquitous, whether there are significant differences in conditions among regions, whether the conditions are changing over time, and why these conditions change from place to place and over time. The information can be used to help determine the efficacy of existing water-quality policies and to help analysts determine the need for and likely consequences of new policies.

To address these needs, the Congress appropriated funds in 1986 for the USGS to begin a pilot program in seven project areas to develop and refine the National Water-Quality Assessment (NAWQA) Program. In 1991, the USGS began full implementation of the program. The NAWQA Program builds upon an existing base of water-quality studies of the USGS, as well as those of other Federal, State, and local agencies. The objectives of the NAWQA Program are to:

- Describe current water-quality conditions for a large part of the Nation's freshwater streams, rivers, and aquifers.

- Describe how water quality is changing over time.

- Improve understanding of the primary natural and human factors that affect water-quality conditions.

This information will help support the development and evaluation of management, regulatory, and monitoring decisions by other Federal, State, and local agencies to protect, use, and enhance water resources.

The goals of the NAWQA Program are being achieved through ongoing and proposed investigations of 51 of the Nation's most important river basins and aquifer systems, which are referred to as study units. These study units are distributed throughout the Nation and cover a diversity of hydrogeologic settings. More than two-thirds of the Nation's freshwater use occurs within the 51 study units and more than two-thirds of the people served by public water-supply systems live within their boundaries.

National synthesis of data analysis, based on aggregation of comparable information obtained from the study units, is a major component of the program. This effort focuses on selected water-quality topics using nationally consistent information. Comparative studies will explain differences and similarities in observed water-quality conditions among study areas and will identify changes and trends and their causes. The first topics addressed by the national synthesis are pesticides, nutrients, volatile organic compounds, and aquatic biology. Discussions on these and other waterquality topics will be published in periodic summaries of the quality of the Nation's ground and surface water as the information becomes available.

This report is an element of the comprehensive body of information developed as part of the NAWQA Program. The program depends heavily on the advice, cooperation, and information from many Federal, State, interstate, Tribal, and local agencies and the public. The assistance and suggestions of all are greatly appreciated.

Robert M. Hirsch

Chief Hydrologist 


\section{CONTENTS}

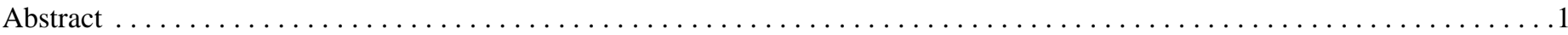

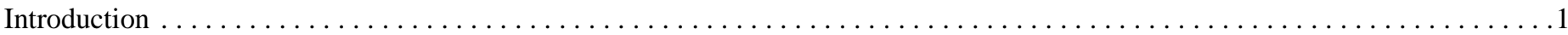

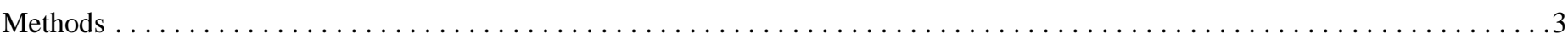

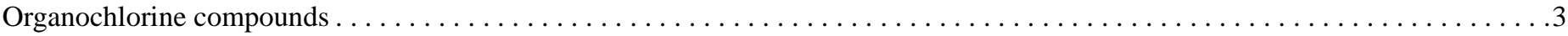

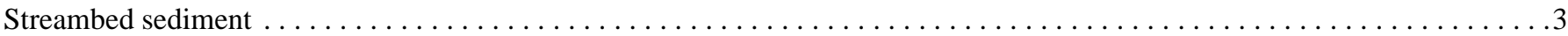

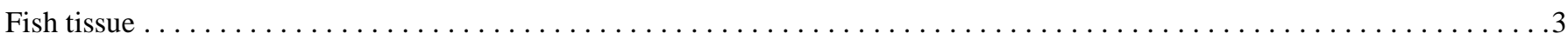

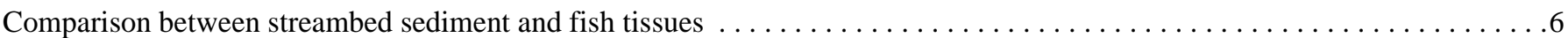

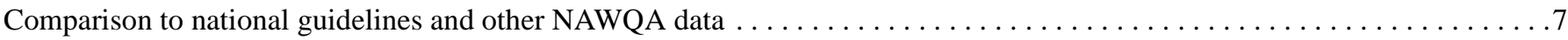

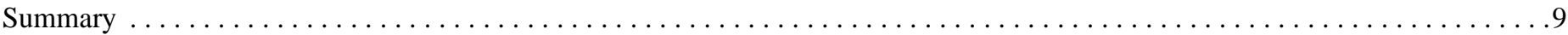

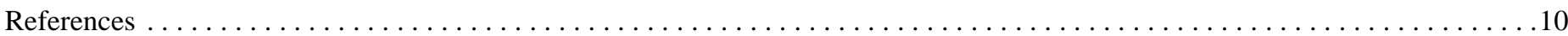

\section{ILLUSTRATIONS}

Figure 1. Maps showing location of streambed sediment and fish tissue sampling sites in the Upper Mississippi River Basin

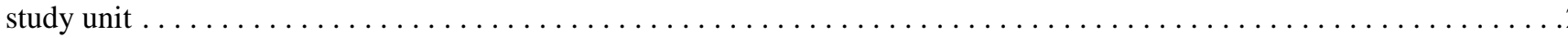

Figures 2-5. Graphs showing:

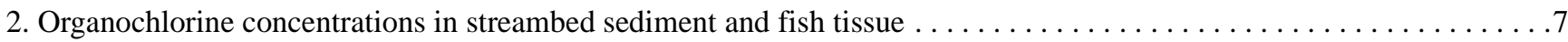

3. Concentrations of p,p'-DDT and metabolites in streambed sediment, and comparison to national percentile concentrations of total DDT based on 1991-94 NAWQA study unit data. . . . . . . . . . . . . . . . . . . .8

4. Detected concentrations of total polychlorinated biphenyls in fish tissue and streambed sediment, and comparison to national percentile concentrations of total DDT based on 1991-94 NAWQA study unit data . . . . . . . . . . .8

5. Concentrations of p,p'-DDT and metabolites in fish tissues, and comparison to national percentile

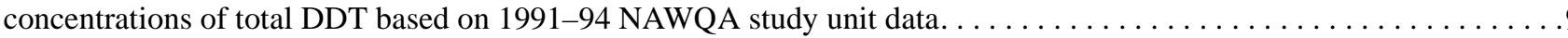

\section{TABLES}

Table 1. Sites at which streambed sediment and fish tissue were sampled in the Upper Mississippi River Basin

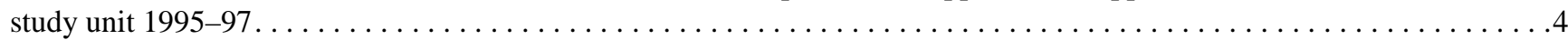

2. Organochlorine compounds analyzed and method reporting limits in streambed sediment and fish tissue samples

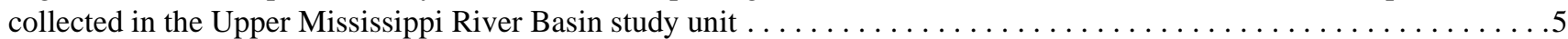

3. Fish species obtained in the study unit for analysis of organochlorine compounds in the Upper Mississippi River

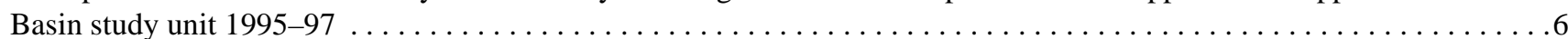

\section{CONVERSION FACTORS AND ABBREVIATED WATER QUALITY UNITS}

\section{Multiply}

inch (in.)

square mile $\left(\mathrm{mi}^{2}\right)$

ounce (oz.) by

2.54

2.590

28.35 to obtain

centimeter square kilometer gram

Concentrations of constituents in streambed sediment and fish tissues are given in micrograms per kilogram. A microgram is one-millionth of a gram. A gram is one-thousandth of a kilogram. 


\section{Water-Quality Assessment of Part of the}

Upper Mississippi River Basin, Minnesota

and Wisconsin-Organochlorine Compounds

in Streambed Sediments and Fish Tissues,

1995-97

by R.P. McNellis, J.D. Fallon, and K.E. Lee

ABSTRACT

Streambed sediments and fish tissues were collected in part of the Upper Mississippi River Basin to assess the presence and distribution of organochlorine compounds (OCs) including PCBs. A total of 13 OCs were detected among 14 of 27 streambed sediment sampling locations. In fish tissues analyzed, 9 OCs were detected among 17 of 24 sites sampled. Eight OCs were detected in both fish and streambed sediment samples, they were: cis-chlordane, $o, p^{\prime}$-DDD; $p, p^{\prime}$-DDD; $p, p^{\prime}$-DDE; $p, p$ '-DDT; hexachlorobenzene; transnonachlor; and PCBs. The most frequently detected OCs were: $p, p^{\prime}$-DDE; and $p, p^{\prime}$-DDD in streambed sediment and $p, p^{\prime}$-DDE and PCBs in fish tissues. No OCs were detected in streambed sediment at agricultural sites; however, the agricultural sites had 17 detections of OCs in fish tissue. Urban streams had concentrations of total DDT and metabolites in streambed sediment that exceed guidelines for classification of sites with high probabilities of adverse effects to aquatic organisms. Total DDT was the only OC within an urban land use that exceeded guidelines for piscivorous wildlife

\section{INTRODUCTION}

In 1994, the U.S. Geological Survey's (USGS) National Water-Quality Assessment (NAWQA) Program began studies in part of the Upper Mississippi River Basin (UMIS) located in Minnesota and Wisconsin (fig.1). Goals of the NAWQA Program are to document the quality of surface and ground water throughout the Nation and to explain natural and anthropogenic factors affecting water quality and trends over time. A specific objective of the UMIS NAWQA study was to determine the presence and distribution of organochlorine compounds in streambed sediment and fish tissues among the major land use settings of the UMIS study unit.

Organochlorine compounds (including polychlorinated biphenyls), hereinafter referred to as OCs, are hydrophobic compounds that are persistent in the environment because they are resistant to rapid decomposition. OCs tend to be sorbed to sediments and are transported and deposited with sediments. OCs such as $p, p$ '-DDT and polychlorinated biphenyls (PCBs) were widely used pesticides and industrial products from the 1940's into the 1970's when their use was discontinued (Larson and others, 1997). Several others, such as the insecticide endosulfan I, are still used today in agriculture. OCs were frequently used as pesticides in agricultural and urban areas, but generally had fewer applications in forested environments. OC use may have been most intense in urban areas due to frequent $p, p$ '-DDT applications for mosquito control and industrial uses of PCBs as high temperature lubricants and insulators.

Atmospheric deposition and sediment resuspension continue to recirculate OCs to water and biota. OCs are a concern because they can bioaccumulate in fish tissue and because some pose health risks to the environment, such as thinning of bald eagle egg shells (U.S. Environmental Protection Agency, 1992). Several OCs are probable carcinogens in humans (U.S. Environmental Protection Agency, 1996) and exposure to these OCs could occur from eating contaminated fish. The
Minnesota Department of Health (1999) has issued fish consumption advisories based upon the PCB concentrations in fillets and the frequency with which fish are included in an individual's diet. Fish and streambed sediment samples in the UMIS study unit were analyzed for OCs as part of the NAWQA Program. This report presents the results of those analyses.

The types and concentrations of OCs used in the UMIS study unit may relate to land use. Therefore, the data analyzed were categorized by land use to give a general perspective of where OCs may be prevalent and thus might have a significant effect to the health of humans and the environment. The land uses in the UMIS consist of an agricultural zone across the southwestern one-third of the study unit; a forested zone across the northeastern one-third of the study unit; and a transitional zone in between (fig. 1). Urban land use accounts for about 2 percent of the study unit and is concentrated around the Twin Cities metropolitan area (TCMA) (Stark and others, 1999). 


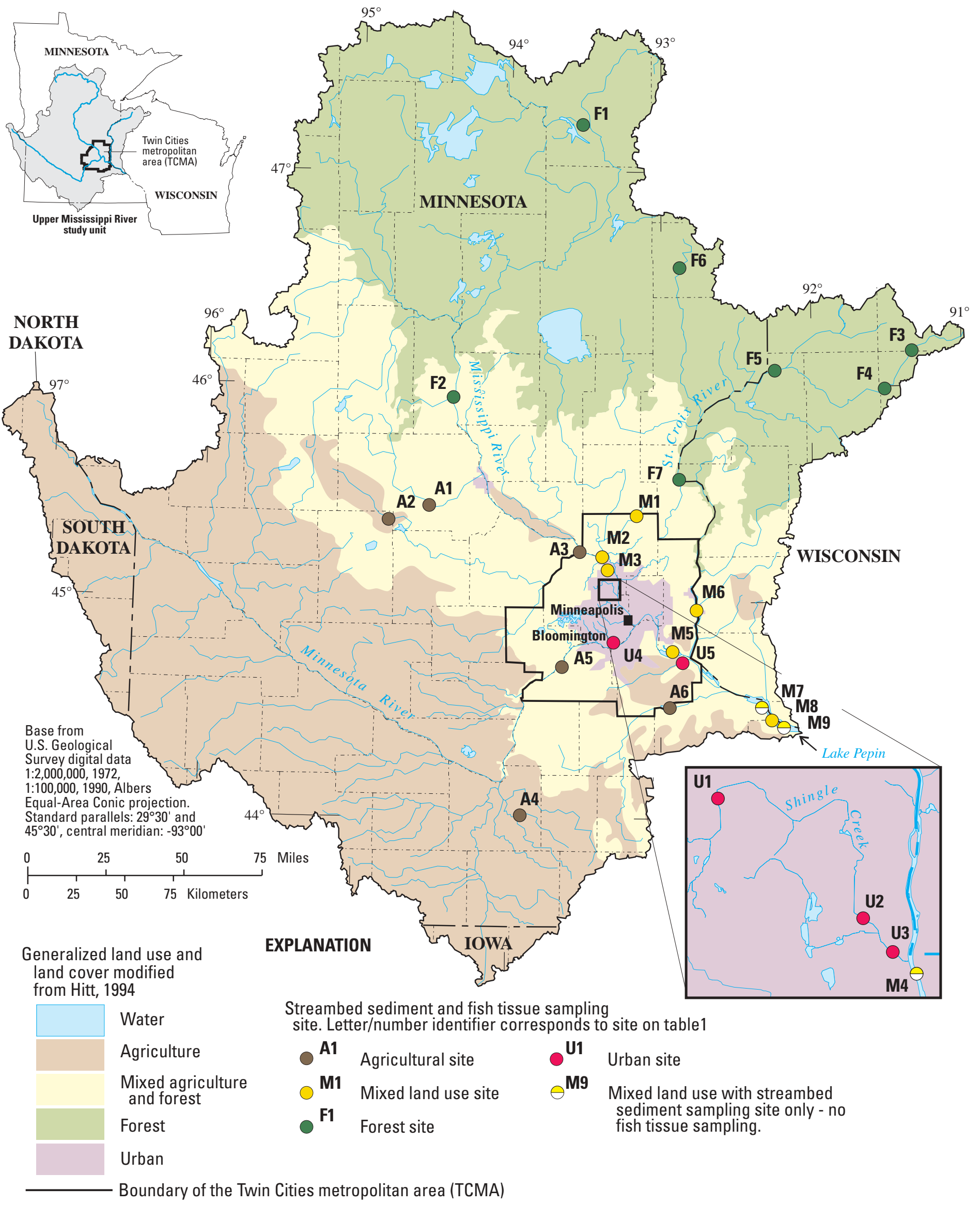

Figure 1.--Location of streambed sediment and fish tissue sampling sites in the Upper Mississippi River Basin study unit. 


\section{METHODS}

Streambed sediment and fish tissues were collected once from 27 and 24 sites, respectively, during low flow conditions (July-November) from 1995 through 1997 (fig. 1, table 1). Sites were selected within the major land uses in the basin and along major tributaries to the Mississippi River. Sites were selected to maximize the probability of OC detections within the major land use settings of the UMIS (Stark and others, 1999). At a subset of sites, more than one sediment or fish sample was collected to assess variability (table 3). Percentages of land use (forested and wetland, agricultural, urban, water, or other, which includes rangeland) were computed for basins upstream of each site. Streams were classified by the predominant land use of each basin. Streams were classified as forested if they drained greater than or equal to 65 percent forests and wetlands; agricultural if they drained greater than 80 percent agricultural area, urban if they were located in the TCMA and drained greater than 15 percent urban area, and mixed if they fell between these categories. Additional characteristics of stream sites sampled in this investigation are given in Stark and others (1999).

At each site approximately the upper 1 inch of recently deposited streambed sediment was collected from 5 to 10 depositional areas near both banks and the center of the stream using methods described by Shelton and Capel (1994). A composite was made from these subsamples and passed through a $2 \mu \mathrm{m}$ (micrometer) stainless steel sieve to obtain a sand or finer grained representative sample of depositional streambed sediment at each site. Streambed sediment composites were analyzed for 32 OCs (table 2) by gas chromatography with electron-capture detection (Foreman and others, 1995) at the USGS National Water Quality Laboratory in Arvada, Colo.

Common carp, white sucker, shorthead redhorse and golden redhorse were collected, depending on availability at each site (table 3 ). These species feed on invertebrates and detritus on the stream bottom. Bottom feeders were chosen because OCs sorb to sediments, and because detritivores are likely to be exposed to OCs through ingestion of contaminated sediment. Five to 10 fish of a single species were collected at each site with electrofishing equipment. Efforts were made to collect similarly aged adult fish for each site, but this was not always possible. At selected sites 2 species were collected, composited, and analyzed separately to assess interspecies variability (table 3). At site A6 a duplicate sample of common carp was collected to assess intraspecies variability. Whole fish tissues were analyzed at the U.S. Geological Survey's National Water Quality Laboratory in Arvada, Colo. At the laboratory, fish from each respective site were composited into a single sample for analysis. Whole fish composites were analyzed for 28 OCs (table 2) by dual capillary-column gas chromatography with electron-capture detection that is described in detail by Leiker and others (1995).

Method reporting limits varied between streambed sediment and fish tissue and among the different OCs (table 2). Constituents with concentrations below the method reporting limit were considered to have no detections or concentrations of zero. Streambed sediment and fish tissue data from sites with multiple samples were averaged and considered to be one sample.

\section{ORGANOCHLORINE COMPOUNDS}

\section{Streambed Sediment}

Thirteen OCs were detected in streambed sediment (four were $p, p$ '-DDT and it's metabolites) at one or more sites (fig. 2). Fourteen of 27 sites had one or more detections of OCs. The most frequently detected OCs were $p, p^{\prime}-D D D$, $\mathrm{p}, \mathrm{p}$ '-DDE, and p, p'-DDT. The concentrations of all OCs ranged from 0.3 to 133.3 micrograms per kilogram $(\mu \mathrm{g}$ / $\mathrm{kg}$ ) (fig. 2).

The types and concentrations of OCs in streambed sediment varied by land use. Forest sites had five total detections of three compounds, which were $p, p$ '-DDE, $p, p$ '-DDD, and endosulfan I (fig. 2). Endosulfan I was found in the St. Croix and Namakegon Rivers. Endosulfan I is an insecticide used to control a variety of pests of small fruit and vegetable crops, which are commonly grown in the St. Croix River Basin.

There were no detections of OCs in streambed sediment at any of the agricultural land use sites (fig. 2), indicating that OCs were used less frequently or in lower amounts than in urban streams.

The mixed land use sites had 9 detections of 4 compounds (fig. 2). In order of highest frequency they were: $p, p$ '-DDD, $p, p$ '-DDE, PCBs, and endosulfan I. The mixed land use sites can be characterized generally as large river sites that are located within or downstream of the TCMA. The two detections of PCBs in the mixed land use were both in the upstream portions of Lake Pepin on the Mississippi River. Lake Pepin is a natural river impoundment downstream of the TCMA that is a depositional area for fine-grained sediments. Similar to results reported by Fallon and others (1997), most OC detections were found within or downstream of the TCMA, suggesting that the TCMA is a major source of those compounds.

Twelve of the 13 OCs were found in at least one urban site with the exception being endosulfan I. Historically, urban areas have had high OC use, mainly $p, p$ 'DDT for insect control and PCBs for industrial applications. All of the urban streams had detections of $p, p$ '-DDT and the degradation compounds $p, p$ '-DDE and $p, p$ '-DDD (fig. 3) indicating high or frequent $p, p$-DDT use in the past. One urban stream sampled had detections of total PCB concentrations greater than the method reporting limit of $50 \mu \mathrm{g} / \mathrm{kg}$ (U2, Shingle Creek at Queen Avenue in Minneapolis) (fig. 4).

\section{Fish Tissue}

Nine OCs were detected in fish tissue (four were $p, p$ '-DDT and it's metabolite) (fig. 2). Seventeen of 24 sites had at least one OC detection (fig. 5). The most frequently detected was $p, p$ '-DDE, which was detected at 17 sites. Total PCBs were the next most frequently detected OC with detections at 13 sites. Concentrations of all OCs ranged from 2.6 to $680 \mu \mathrm{g} / \mathrm{kg}$ (fig. 2).

The types and concentrations of OCs 
Table 1. Sites at which streambed sediment and fish tissue were sampled in the Upper Mississippi River Basin study unit, 1995-97

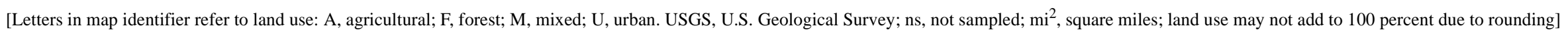

\begin{tabular}{|c|c|c|c|c|c|c|c|c|c|c|c|}
\hline \multirow{2}{*}{$\begin{array}{c}\text { Map } \\
\text { identifier } \\
\text { (figure 1) }\end{array}$} & \multirow[b]{2}{*}{$\begin{array}{l}\text { USGS site } \\
\text { identifier }\end{array}$} & \multirow[b]{2}{*}{ Site name } & \multirow[b]{2}{*}{ Latitude } & \multirow[b]{2}{*}{ Longitude } & \multicolumn{2}{|c|}{ Sampling date } & \multicolumn{4}{|c|}{ Land use (percent) } & \multirow[b]{2}{*}{$\begin{array}{l}\text {-Drainage } \\
\text { area } \\
\left(\mathrm{mi}^{2}\right)\end{array}$} \\
\hline & & & & & Sediment & Fish & Urban & $\begin{array}{l}\text { Agricul- } \\
\text { ture }\end{array}$ & $\begin{array}{c}\text { Forest } \\
\text { and }\end{array}$ & $\begin{array}{c}\text { Water } \\
\text { and other }\end{array}$ & \\
\hline$\overline{\mathrm{A} 1}$ & 05270380 & Sauk River at Richmond, Minn. & $45^{\circ} 26^{\prime} 56^{\prime \prime}$ & $94^{\circ} 31^{\prime} 30^{\prime \prime}$ & $7 / 20 / 95$ & $7 / 19 / 95$ & 0.9 & 84 & 11.1 & 4.3 & 819 \\
\hline $\mathrm{A} 2$ & 05276005 & North Fork Crow River above Paynesville, Minn. & $45^{\circ} 22^{\prime} 38^{\prime \prime}$ & $94^{\circ} 47^{\prime} 00^{\prime \prime}$ & $\begin{array}{l}7 / 17 / 95 \\
9 / 19 / 96\end{array}$ & $9 / 16 / 96$ & 0.3 & 90 & 7.7 & 1.8 & 232 \\
\hline A3 & 05280400 & Crow River below State Highway 101 at Dayton, Minn. & $45^{\circ} 13^{\prime} 20^{\prime \prime}$ & $93^{\circ} 31^{\prime} 12^{\prime \prime}$ & $7 / 24 / 95$ & $7 / 18 / 95$ & 1.4 & 87 & 6.1 & 5.1 & 2,760 \\
\hline A4 & 05320270 & Little Cobb River near Beauford, Minn. & $43^{\circ} 59^{\prime} 48^{\prime \prime}$ & $93^{\circ} 54^{\prime} 30^{\prime \prime}$ & $\begin{array}{c}8 / 2 / 95 \\
9 / 18 / 96\end{array}$ & $7 / 9 / 97$ & 0.2 & 94 & 0.9 & 0.6 & 130 \\
\hline A5 & 05330000 & Minnesota River near Jordan, Minn. & $44^{\circ} 41^{\prime} 35^{\prime \prime}$ & $93^{\circ} 38^{\prime} 30^{\prime \prime}$ & $7 / 11 / 95$ & $7 / 10 / 95$ & 0.9 & 94 & 2.8 & 2.4 & 16,200 \\
\hline A6 & 05355090 & Cannon River at Lake Byllesby near Cannon Falls, Minn. & $44^{\circ} 30^{\prime} 35^{\prime \prime}$ & $92^{\circ} 57^{\prime} 00^{\prime \prime}$ & $7 / 21 / 95$ & $7 / 17 / 95$ & 3.1 & 89 & 4.9 & 3.3 & 1,150 \\
\hline $\mathrm{F} 1$ & 05211000 & Mississippi River at Grand Rapids, Minn. & $47^{\circ} 13^{\prime} 56^{\prime \prime}$ & $93^{\circ} 31^{\prime} 48^{\prime \prime}$ & $7 / 25 / 95$ & $7 / 24 / 95$ & 0.4 & 8.8 & 74 & 16.8 & 3,320 \\
\hline F2 & 05263500 & Mississippi River below Little Falls, Minn. & $45^{\circ} 56^{\prime} 22^{\prime \prime}$ & $94^{\circ} 23^{\prime} 20^{\prime \prime}$ & $7 / 24 / 95$ & $7 / 20 / 95$ & 0.6 & 24 & 65 & 9.6 & 11,400 \\
\hline F3 & 05331833 & Namekagon River at Leonards, Wisc. & $46^{\circ} 10^{\prime} 18^{\prime \prime}$ & $91^{\circ} 19^{\prime} 50^{\prime \prime}$ & $7 / 19 / 95$ & $7 / 25 / 95$ & 0.7 & 1.8 & 90 & 7.3 & 126 \\
\hline F4 & 05331873 & Namekagon River above Spring Lake Creek near Hayward, Wisc. & $45^{\circ} 59^{\prime} 22^{\prime \prime}$ & $91^{\circ} 30^{\prime} 33^{\prime \prime}$ & $9 / 17 / 96$ & $10 / 26 / 96$ & 1.4 & 5.5 & 87.6 & 5.4 & 208 \\
\hline F5 & 05333500 & St. Croix River near Danbury, Wisc. & $46^{\circ} 04^{\prime} 28^{\prime \prime}$ & $92^{\circ} 14^{\prime} 50^{\prime \prime}$ & $7 / 19 / 95$ & $9 / 27 / 95$ & 0.3 & 4.9 & 91 & 4.3 & 1,580 \\
\hline F6 & 05336180 & Kettle River near Kettle River, Minn. & $46^{\circ} 29^{\prime} 03^{\prime \prime}$ & $92^{\circ} 53^{\prime} 19^{\prime \prime}$ & $8 / 1 / 95$ & $9 / 27 / 95$ & 0.0 & 23.4 & 75.9 & 0.7 & 157 \\
\hline F7 & 05339770 & St. Croix River near Sunrise, Minn. & $45^{\circ} 34^{\prime} 14^{\prime \prime}$ & $92^{\circ} 52^{\prime} 30^{\prime \prime}$ & $7 / 20 / 95$ & $7 / 14 / 95$ & 0.4 & 24 & 74 & 3 & 5,510 \\
\hline M1 & 05286290 & Cedar Creek near Coopers Corner, Minn. & $45^{\circ} 23^{\prime} 31^{\prime \prime}$ & $93^{\circ} 12^{\prime} 44^{\prime \prime}$ & $9 / 16 / 96$ & $10 / 4 / 96$ & 0.1 & 69 & 30.8 & 0 & 27.3 \\
\hline M2 & 05287000 & Rum River at Anoka, Minn. & $45^{\circ} 11^{\prime} 54^{\prime \prime}$ & $93^{\circ} 23^{\prime} 28^{\prime \prime}$ & $7 / 21 / 95$ & $7 / 21 / 95$ & 0.7 & 49 & 35 & 15.6 & 1,580 \\
\hline M3 & 05288500 & Mississippi River near Anoka, Minn. & $45^{\circ} 07^{\prime} 36^{\prime \prime}$ & $93^{\circ} 17^{\prime} 48^{\prime \prime}$ & $7 / 13 / 95$ & $7 / 18 / 95$ & 1.1 & 45 & 46 & 8.3 & 19,100 \\
\hline M4 & 05288730 & Mississippi River at 28th Ave. NE in Minneapolis, Minn. & $45^{\circ} 01^{\prime} 12^{\prime \prime}$ & $93^{\circ} 16^{\prime} 31^{\prime \prime}$ & $9 / 27 / 96$ & ns & 1.7 & 44 & 55 & 8.3 & 19,600 \\
\hline M5 & 05331570 & Mississippi River at Nininger, Minn. & $44^{\circ} 46^{\prime} 22^{\prime \prime}$ & $92^{\circ} 54^{\prime} 07^{\prime \prime}$ & $7 / 12 / 95$ & $7 / 11 / 95$ & 2.5 & 66 & 26.1 & 5.6 & 37,000 \\
\hline M6 & 05341552 & St. Croix River at Hudson, Wisc. & $44^{\circ} 58^{\prime} 57^{\prime \prime}$ & $92^{\circ} 46^{\prime} 07^{\prime \prime}$ & $7 / 14 / 95$ & $7 / 14 / 95$ & 0.7 & 34 & 62 & 3.4 & 7,340 \\
\hline M7 & 442633092130801 & Mississippi River in Lake Pepin near Lake City, Minn. & $44^{\circ} 26^{\prime} 33^{\prime \prime}$ & $92^{\circ} 13^{\prime} 08^{\prime \prime}$ & $7 / 28 / 95$ & ns & 2.3 & 62 & 29.7 & 5.2 & 47,300 \\
\hline M8 & 442912092174201 & Mississippi River in Lake Pepin near Central Point, Minn. & $44^{\circ} 29^{\prime} 12^{\prime \prime}$ & $92^{\circ} 17^{\prime} 42^{\prime \prime}$ & $7 / 28 / 95$ & $7 / 13 / 95$ & 2.3 & 62 & 29.7 & 5.2 & 47,300 \\
\hline M9 & 443334092205201 & Mississippi River in Lake Pepin near Frontenac, Minn. & $44^{\circ} 33^{\prime} 34^{\prime \prime}$ & $92^{\circ} 20^{\prime} 52^{\prime \prime}$ & $7 / 28 / 95$ & ns & 2.3 & 62 & 29.7 & 5.2 & 47,300 \\
\hline U1 & 05288695 & Shingle Creek at Zane Ave. at Brooklyn Park, Minn. & $45^{\circ} 05^{\prime} 31 "$ & $93^{\circ} 21^{\prime} 23^{\prime \prime}$ & 9/27/96 & $9 / 19 / 96$ & 57 & 30 & 2.3 & 11 & 19.2 \\
\hline $\mathrm{U} 2$ & 05288705 & Shingle Creek at Queen Ave. in Minneapolis, Minn. & $45^{\circ} 03^{\prime} 00^{\prime \prime}$ & $93^{\circ} 18^{\prime} 36^{\prime \prime}$ & $9 / 26 / 96$ & $9 / 17 / 96$ & 71 & 20 & 1.6 & 7.5 & 28.2 \\
\hline $\mathrm{U} 3$ & 05288710 & Shingle Creek at 46th Street in Minneapolis, Minn. & $45^{\circ} 02^{\prime} 18^{\prime \prime}$ & $93^{\circ} 17^{\prime} 47^{\prime \prime}$ & $7 / 18 / 95$ & $8 / 28 / 95$ & 79 & 14 & 1.1 & 6.3 & 40.8 \\
\hline $\mathrm{U} 4$ & 05330902 & Nine Mile Creek near James Circle at Bloomington, Minn. & $44^{\circ} 48^{\prime} 26^{\prime \prime}$ & $93^{\circ} 18^{\prime} 05^{\prime \prime}$ & $7 / 18 / 95$ & $7 / 26 / 95$ & 87 & 5.7 & 3.9 & 3.7 & 44.6 \\
\hline U5 & 05345000 & Vermillion River near Empire, Minn. & $44^{\circ} 40^{\prime} 00^{\prime \prime}$ & $93^{\circ} 03^{\prime} 17^{\prime \prime}$ & $7 / 18 / 95$ & $7 / 12 / 95$ & 16 & 76 & 4.4 & 2.9 & 129 \\
\hline
\end{tabular}


Table 2. Organochlorine compounds analyzed and method reporting limits in streambed sediment and fish tissue samples collected in the Upper Mississippi River Basin study unit $[\mu \mathrm{g} / \mathrm{kg}$, micrograms per kilogram]

\begin{tabular}{|c|c|c|}
\hline \multirow[b]{2}{*}{ Constituent } & \multicolumn{2}{|c|}{ Method reporting limit } \\
\hline & $\begin{array}{c}\text { Stream bed } \\
\text { sediments } \\
(\mu \mathrm{g} / \mathrm{kg})\end{array}$ & $\begin{array}{l}\text { Fish tissue } \\
(\mu \mathrm{g} / \mathrm{kg})\end{array}$ \\
\hline Aldrin & 1 & 5 \\
\hline cis-chlordane & 1 & ${ }^{1} 5-11$ \\
\hline trans-chlordane & 1 & ${ }^{1} 5-10$ \\
\hline Chloroneb & 5 & Not analyzed \\
\hline Dacthal & 5 & ${ }^{1} 5-20$ \\
\hline$o, p^{\prime}-\mathrm{DDD}$ & ${ }^{1} 1-3.4$ & $15-45$ \\
\hline$p, p$ '-DDD & ${ }^{1} 1-2$ & ${ }^{1} 5-50$ \\
\hline$o, p$ '-DDE & 1 & ${ }^{1} 5-10$ \\
\hline$p, p$ '-DDE & 1 & 5 \\
\hline$o, p$ '-DDT & $12-4$ & ${ }^{1} 5-25$ \\
\hline$p, p^{\prime}$-DDT & 2 & $15-25$ \\
\hline Dieldrin & ${ }^{1} 1-3.2$ & ${ }^{1} 5-11$ \\
\hline Endosulfan I & 1 & Not analyzed \\
\hline Endrin & 2 & ${ }^{1} 5-10$ \\
\hline Heptachlor & 1 & 5 \\
\hline Heptachlor epoxide & 1 & ${ }^{1} 5-20$ \\
\hline Hexachlorobenzene $^{2}$ & ${ }^{1} 1-50$ & 5 \\
\hline$\alpha$-hexachlorocyclohexane $(\alpha-\mathrm{HCH})$ & 1 & ${ }^{1} 5-15$ \\
\hline$\beta$-hexachlorocyclohexane $(\beta-\mathrm{HCH})^{2}$ & ${ }^{1} 1-1.2$ & ${ }^{1} 5-30$ \\
\hline$\delta$-hexachlorocyclohexane $(\delta$-HCH $)$ & Not analyzed & ${ }^{1} 5-18$ \\
\hline Isodrin & 1 & Not analyzed \\
\hline Lindane $(\gamma-\mathrm{HCH})$ & 1 & ${ }^{1} 5-20$ \\
\hline$o, p$ '-methoxychlor & ${ }^{1} 5-39$ & ${ }^{1} 5-10$ \\
\hline$p, p$ '-methoxychlor & ${ }^{1} 5-5.2$ & ${ }^{1} 5-25$ \\
\hline Mirex & 1 & ${ }^{1} 5-10$ \\
\hline cis-nonachlor & 1 & ${ }^{1} 5-10$ \\
\hline trans-nonachlor & 1 & ${ }^{1} 5-10$ \\
\hline Oxychlordane & 1 & ${ }^{1} 5-15$ \\
\hline PCBs, total & 50 & 50 \\
\hline Pentachloroanisole & ${ }^{1} 1-50$ & ${ }^{1} 5-25$ \\
\hline cis-permethrin & ${ }^{1} 5-15$ & Not analyzed \\
\hline trans-permethrin & ${ }^{1} 5-44$ & Not analyzed \\
\hline Toxaphene & 200 & $1_{200-2,100}$ \\
\hline
\end{tabular}

1 The method reporting limit for this constituent varied among the samples

${ }^{2}$ There was no tissue analysis for this constituent at Namakegon River above Spring Lake Creek near Hayward, Wisconsin. in fish tissue varied by land use. The forest sites had fewer detections than the other land uses (fig. 2), probably attributable to fewer potential sources in forested areas. There were three detections of $p, p$ '-DDE and one detection of PCBs at forested sites. Concentrations of OCs also were lower at forested than at sites in other land uses. In contrast, agricultural sites had the most types of OCs (eight) detected in fish tissue (fig.

$2)$. The most frequent detections at agricultural sites was $p, p$ '-DDE. PCBs and $p, p$ '-DDE accounted for most of the OC detections in fish tissue at the mixed land use sites (fig. 2). At urban sites, seven OCs were detected in fish tissue. Four of the OCs detected at urban sites were $p, p$-DDT and degradation products; the other three were total PCBs, cis-chlordane, and transnonachlor. Although DDT and degradation products were detected in fish tissue samples in all four land uses, the concentrations at the urban sites generally were greater than those of the other land uses (figs. 2 and 5). Urban areas may have had longer exposure to OCs, which would allow more time for bioaccumulation in fish, and urban areas may have received larger amounts of OCs (particularly $p, p$ '-DDT and PCBs), which would allow for more OCs to be assimilated by fish.

OC concentrations in fish tissue tend to increase in a downstream direction on the Mississippi River. PCB

concentrations in fish tissue were less than $50 \mu \mathrm{g} / \mathrm{kg}$ (not detected) at the Mississippi River at Grand Rapids and typically increased in a downstream direction in the Mississippi River to the outlet of the study unit at Lake Pepin where they were $680 \mu \mathrm{g} / \mathrm{kg}$. This observation is consistent with the findings of Lee and Anderson (1998) who reported increased concentrations of total PCBs below the TCMA between 1975 and 1995. Lee and Anderson (1998) also noted that areas with historically high levels of total PCBs in streambed sediment tend to have higher concentrations of total PCBs in fish tissue, which agrees with the findings at site M9, Mississippi River in Lake Pepin near Central Point, Minn. 
Table 3. Fish species obtained in the study unit for analysis of organochlorine compounds in the Upper Mississippi River Basin study unit, 1995-97

[Map identifier corresponds to site shown in figure 1; na, not available]

\begin{tabular}{|c|c|c|c|c|}
\hline $\begin{array}{c}\text { Map } \\
\text { identifier }\end{array}$ & Site name & $\begin{array}{c}\text { Fish species } \\
\text { (common name) }\end{array}$ & $\begin{array}{l}\text { Average total } \\
\text { length } \\
\text { (inches) }\end{array}$ & $\begin{array}{c}\text { Average } \\
\text { weight } \\
\text { (ounces) }\end{array}$ \\
\hline$\overline{\mathrm{A} 1}$ & Sauk River at Richmond, Minn. & Golden redhorse & 16.8 & 34.5 \\
\hline A2 & North Fork Crow River above Paynesville, Minn. & Common carp & 9.7 & 6.1 \\
\hline A3 & Crow River below State Highway 101 at Dayton, Minn. & Shorthead redhorse & 17.9 & 38.8 \\
\hline A4 & Little Cobb River near Beauford, Minn. & Common carp & 17.7 & 45.9 \\
\hline A5 & Minnesota River near Jordan, Minn. & Common carp & 14.6 & 25.4 \\
\hline A6 & Cannon River at Lake Byllesby near Cannon Falls, Minn. & Common carp & 13.9 & 22.3 \\
\hline A6 & Cannon River at Lake Byllesby near Cannon Falls, Minn. & Common carp & 13.6 & 19.6 \\
\hline F1 & Mississippi River at Grand Rapids, Minn. & White sucker & 14.8 & 20.8 \\
\hline $\mathrm{F} 2$ & Mississippi River below Little Falls, Minn. & Shorthead redhorse & 14.5 & 19.7 \\
\hline F3 & Namekagon River at Leonards, Wisc. & White sucker & 8.5 & 3.87 \\
\hline $\mathrm{F} 4$ & Namekagon River above Spring Lake Creek near Hayward, Wisc. & White sucker & 6.1 & 1.4 \\
\hline F5 & St. Croix River near Danbury, Wisc. & Shorthead redhorse & 15.5 & 21.3 \\
\hline F5 & St. Croix River near Danbury, Wisc. & Golden redhorse & 15.1 & 21.9 \\
\hline F6 & Kettle River near Kettle River, Minn. & White sucker & 5.9 & 1.31 \\
\hline F7 & St. Croix River near Sunrise, Minn. & Shorthead redhorse & 12.9 & 13.4 \\
\hline M1 & Cedar Creek near Coopers Corner, Minn. & White sucker & 10.2 & 6.4 \\
\hline M2 & Rum River at Anoka, Minn. & Common carp & 19.0 & 54.7 \\
\hline M3 & Mississippi River near Anoka, Minn. & Common carp & 16.9 & 36.7 \\
\hline M4 & Mississippi River at 28th Ave. NE in Minneapolis, Minn. & bed sediment only & na & na \\
\hline M5 & Mississippi River at Nininger, Minn. & Common carp & 15.7 & 30.1 \\
\hline M6 & St. Croix River at Hudson, Wisc. & Common carp & 16.5 & 35.5 \\
\hline M7 & Mississippi River in Lake Pepin near Lake City, Minn. & bed sediment only & na & na \\
\hline M8 & Mississippi River in Lake Pepin near Central Point, Minn. & Common carp & 17.6 & 44.0 \\
\hline M9 & Mississippi River in Lake Pepin near Frontenac, Minn. & bed sediment only & na & na \\
\hline $\mathrm{U} 1$ & Shingle Creek at Zane Ave. at Brooklyn Park, Minn. & White sucker & 11 & 9.1 \\
\hline $\mathrm{U} 2$ & Shingle Creek at Queen Ave. in Minneapolis, Minn. & White sucker & 9 & 4.6 \\
\hline $\mathrm{U} 2$ & Shingle Creek at Queen Ave. in Minneapolis, Minn. & Common carp & 6.7 & 2.7 \\
\hline $\mathrm{U} 3$ & Shingle Creek at 46th Street in Minneapolis, Minn. & White sucker & 7.8 & 2.8 \\
\hline $\mathrm{U} 4$ & Nine Mile Creek near James Circle at Bloomington, Minn. & White sucker & 7.7 & 3.1 \\
\hline U5 & Vermillion River near Empire, Minn. & White sucker & 8.9 & 3.8 \\
\hline
\end{tabular}

\section{Comparison Between} Streambed Sediment and Fish Tissues

Eight compounds were found in both streambed sediment and fish tissue; they were $c i s$-chlordane, $o, p^{\prime}$-DDD, $p, p^{\prime}-\mathrm{DDD}$, $p, p$ 'DDE, $p, p$-DDT, hexachlorobenzene, trans-nonachlor, and PCBs (fig. 2). The concentrations of PCBs and total DDT in fish tissues were greater than most concentrations in streambed sediment.
However, OCs weren't necessarily found in both streambed sediment and fish tissue at the same site. For instance, at agricultural sites, there were no OC detections in streambed sediment, whereas there were 17 detections of OCs in fish tissue. This demonstrates that fish tissue is an important type of sample when determining the distribution and presence of OCs. The lack of OCs in streambed sediment at agricultural sites may indicate that OCs were not used in the same manner as in urban areas and(or) that OCs (particularly $p, p$ 'DDT metabolites and PCBs) don't persist in streambed sediment as in fish tissue. Also, capping, which occurs when sediment is deposited on top of the existing surface of a streambed, may bury contaminants in streambed sediment. Capping in agricultural areas could occur frequently due to the susceptibility of farm fields to erosion. Analyzing a streambed core as opposed to surficial sediments, may yield OC detections from older layers of sediments in the agricultural areas. 


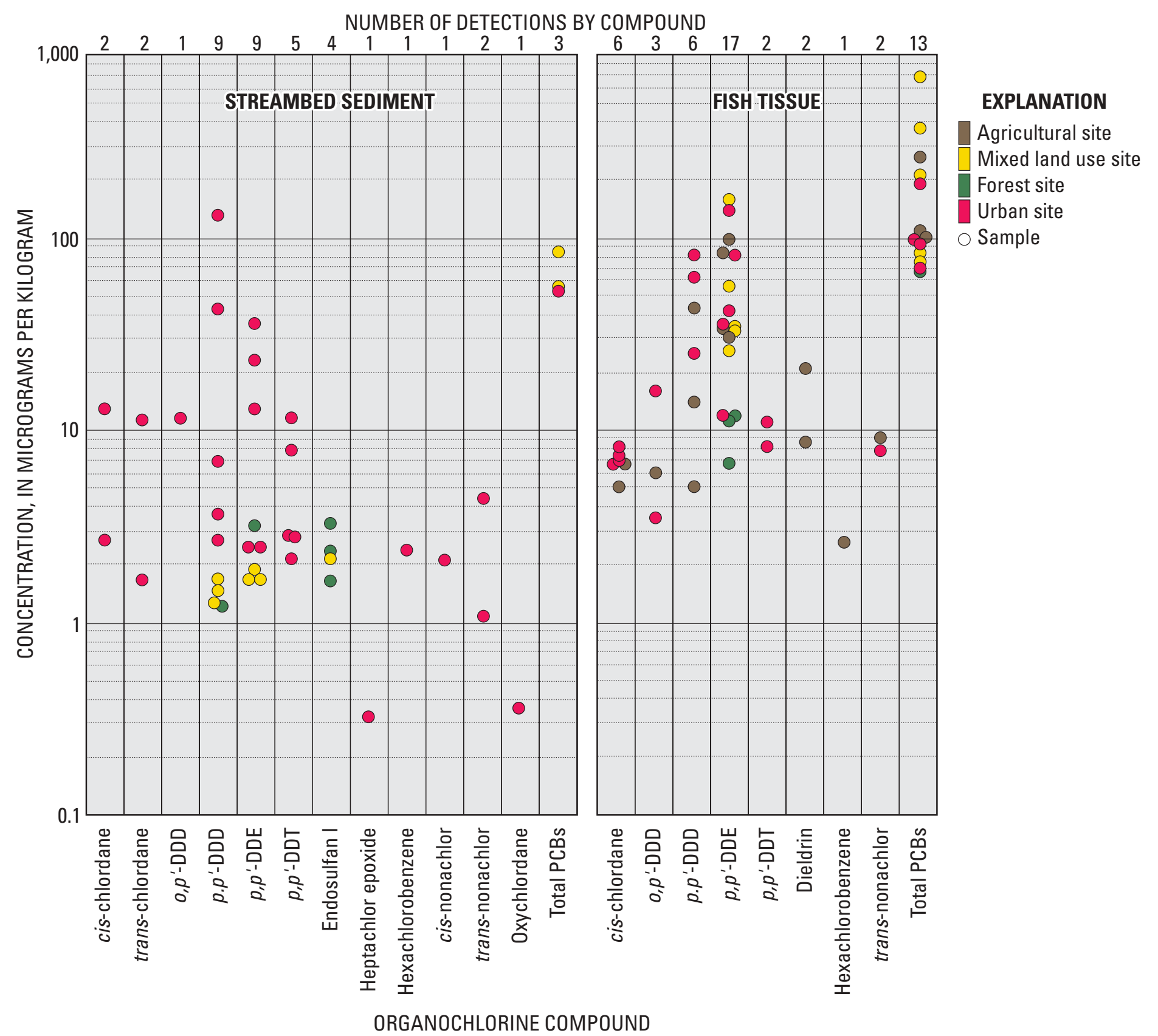

Figure 2.--Organochlorine concentrations in streambed sediment and fish tissue.

\section{Comparison to National Guidelines and Other NAWOA Data}

There are few guidelines for streambed sediment to indicate at what concentration OCs may cause environmental harm. The U.S. Environmental Protection Agency (USEPA) (1997) developed a procedure to estimate the probability of adverse effects to aquatic life from contaminated sediment at sampling sites based on available sediment quality guidelines from multiple agencies. Nowell and others (1999) summarized the USEPA (1997) guidelines to evaluate studies and included additional sediment guidelines from other sources. Nowell and others (1999) guidelines that are applicable to data in this study include: total chlordane (the sum of cis-chlordane, and transchlordane), $6 \mu \mathrm{g} / \mathrm{kg}$; total DDT (sum of all DDT metabolites), $46.1 \mu \mathrm{g} / \mathrm{kg} ; p, p$ 'DDD, $8.51 \mu \mathrm{g} / \mathrm{kg} ; p$, ${ }^{\prime}-\mathrm{DDE}, 15 \mu \mathrm{g} / \mathrm{kg}$; p,p'-DDT, $7 \mu \mathrm{g} / \mathrm{kg}$; and total PCBs, 189 $\mu \mathrm{g} / \mathrm{kg}$. Any site with concentrations exceeding these values would be categorized as having a high probability to affect aquatic life. The only sites with concentrations above these guidelines were located within the TCMA. Shingle Creek at Queen Avenue in Minneapolis had total chlordane detections as high as $26 \mu \mathrm{g} / \mathrm{kg}$. The total DDT and metabolite DDT guidelines were exceeded at various urban sites (fig. 3).

Fish consumption guidelines for edible portions were exceeded in some samples. These guidelines for edible portions were compared to concentrations in whole fish. The USEPA (1995) has set 


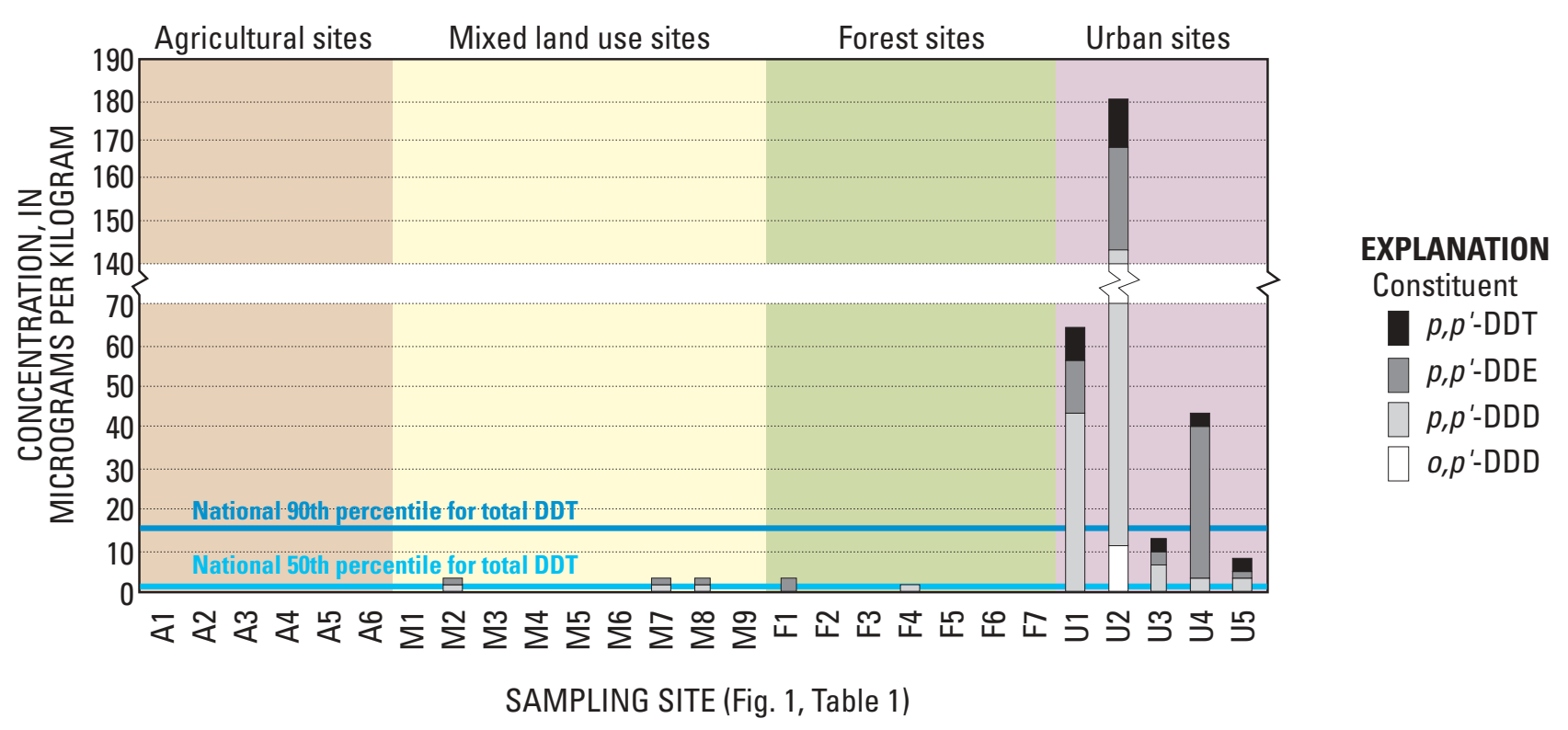

Figure 3.--Concentrations of $p, p^{\prime}$-DDT and metabolites in streambed sediment, and comparison to national percentile concentrations of total DDT based on 1991-94 NAWOA study unit data.

a guideline of $10 \mu \mathrm{g} / \mathrm{kg}$ for PCB concentrations in edible fish tissue with reference to a $70-\mathrm{kg}$ adult eating 6.5 grams of fish per day for a 70-year life span. At least 13 sites exceeded this consumption guideline for PCBs in whole fish (fig. 4) - the guideline is five times lower than the method reporting limit used for analysis herein, thus some sites with concentrations below the method reporting limit may have also exceeded this consumption guidelines in whole fish.

The Minnesota Department of Health (MDH) has also issued advisories concerning the consumption of fish with PCB contamination. The advisories issued suggest how often fish are safe to eat based on the analysis of the skin-on fillet of the fish species in question. Concentrations in whole fish were less than MDH guidelines for unlimited consumption $(50 \mu \mathrm{g} / \mathrm{kg})$ at 11 sites, most of which were forest streams. Fish at nine sites were in the category of one meal per week $(50 \mu \mathrm{g} / \mathrm{kg}-200 \mu \mathrm{g} / \mathrm{kg})$, and four sites were in the category of one meal per month $(200 \mu \mathrm{g} / \mathrm{kg}-1,000 \mu \mathrm{g} / \mathrm{kg}$ ) (Patricia McCann, Minnesota Department of Health, written commun., 1999).

The New York State Department of Environmental Conservation (NYSDEC) (Newell and others, 1987) has guidelines

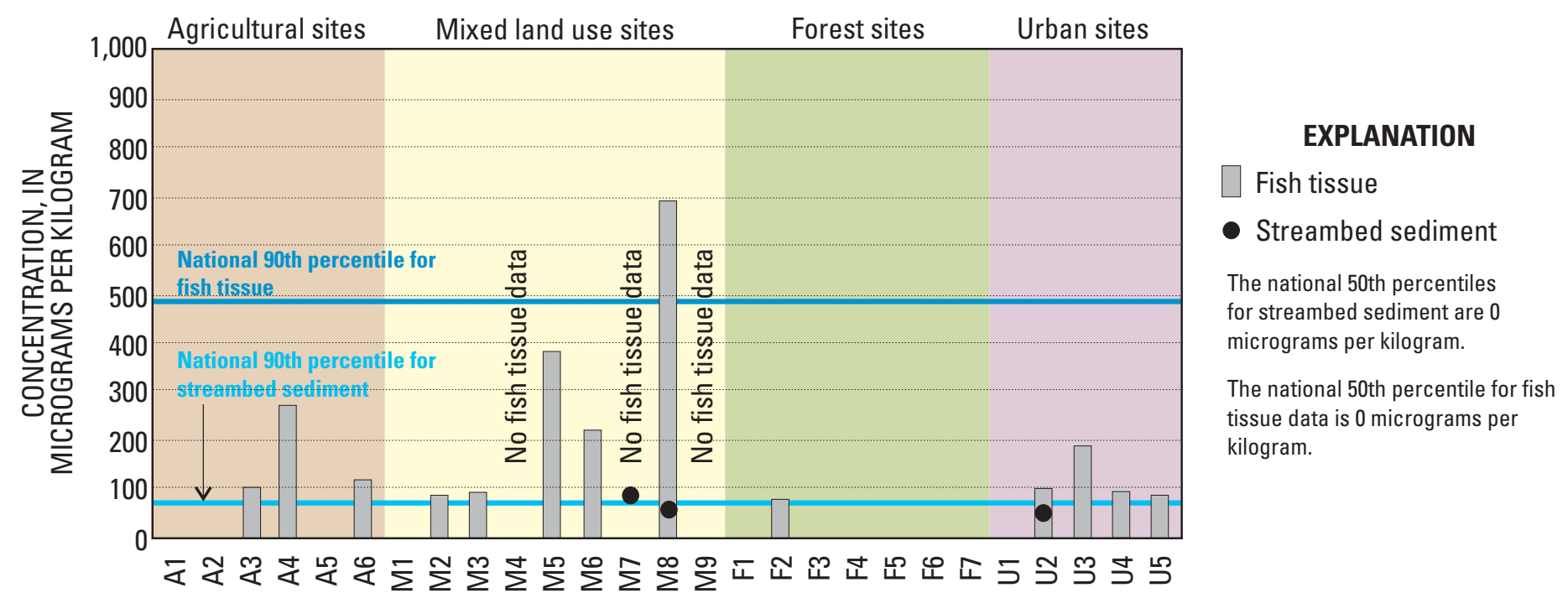

SAMPLING SITE (Fig. 1, Table 1)

Figure 4.--Detected concentrations of total polychlorinated biphenyls in fish tissue and streambed sediment, and comparison to national percentile of concentrations based on 1991-94 NAWOA study unit data. 


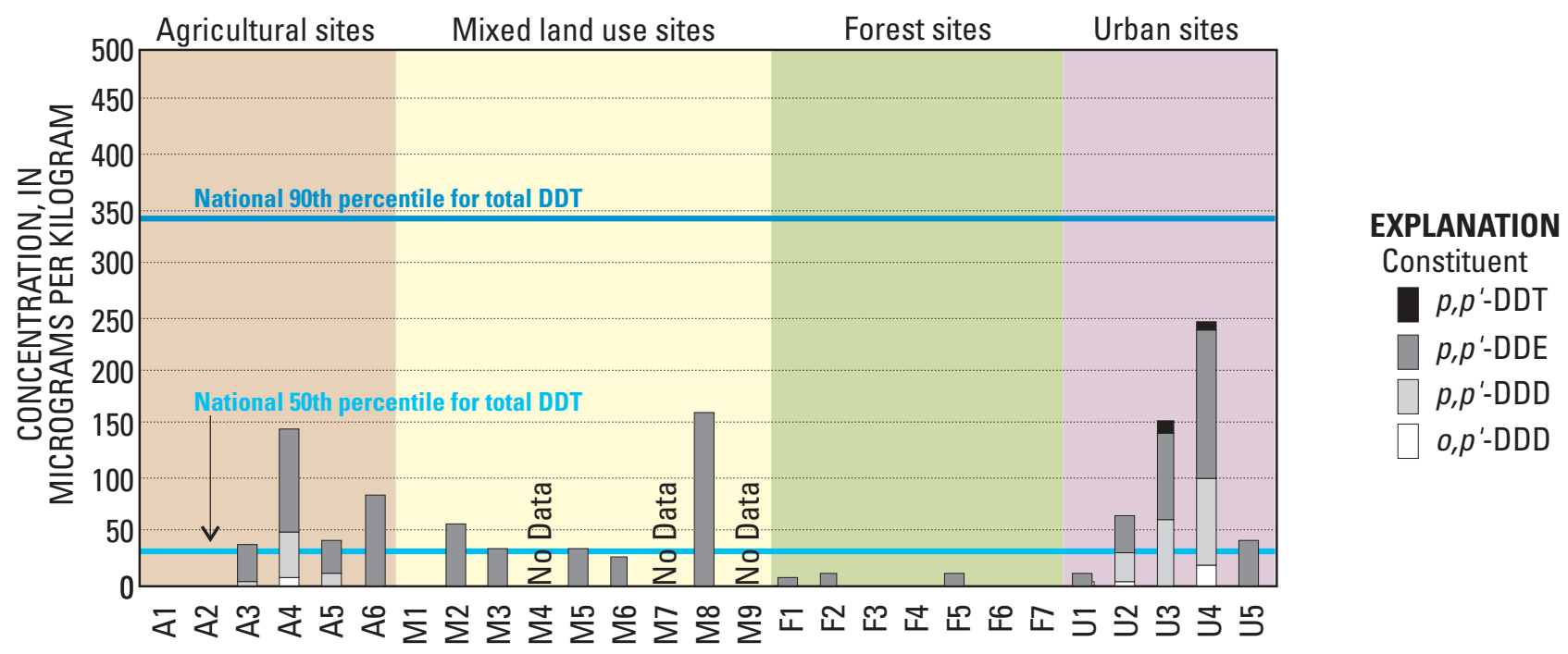

SAMPLING SITE (Fig. 1, Table 1)

Figure 5.--Concentrations of $p, p^{\prime}-\mathrm{DDT}$ and metabolites in fish tissue, and comparison to national percentile concentrations of total DDT based on 1991-94 NAWOA study unit data.

for piscivorous wildlife (mink, otters, etc.). The total DDT guideline from NYSDEC was exceeded only once with a total concentration of $248 \mu \mathrm{g} / \mathrm{kg}$ in whole fish, (guideline is $200 \mu \mathrm{g} / \mathrm{kg}$ in whole fish) at Nine Mile Creek near James Circle at Bloomington, Minn. (U4). NYSDEC guidelines for total PCB concentrations were exceeded at five sites (guideline is $110 \mu \mathrm{g} / \mathrm{kg}$ in whole fish) with regard to picscivorous wildlife; four of these exceedances were at urban or mainstem river sites.

Comparisons were made between the UMIS NAWQA data and data from 20 NAWQA study units that were collected during 1991-93 across the nation. Only total p,p'-DDT and total PCB concentrations for streambed sediment and fish tissue data were compared. Three urban sites within the TCMA exceeded the national $90^{\text {th }}$ percentile for total DDT concentrations (fig. 3) in streambed sediments. One site exceeded the $90^{\text {th }}$ percentile for total PCBs in streambed sediments (fig. 4). In fish tissues, no sites exceeded the 90th percentile fot DDT and it's metabolites; however, 12 sites were greater than the $50^{\text {th }}$ percentile for total DDT (fig. 5). Total PCB concentrations in fish tissue were greater than the 90th percentile at one site, and greater than the 50th percentile at 13 sites (fig. 4).

\section{SUMMARY}

In 1994, the U.S. Geological Survey's (USGS) National Water-Quality Assessment (NAWQA) Program began studies in part of the Upper Mississippi River Basin (UMIS) located in Minnesota and Wisconsin. Streambed sediments and fish tissues were collected in the UMIS to assess the presence and distribution of organochlorine compounds (OCs) and PCBs. The types and concentrations of OCs used in the UMIS study unit may relate to land use. Therefore, the data analyzed were categorized by land use to give a general perspective of where OCs may be prevalent and thus might have a significant effect to the health of humans and the environment.

A total of 13 OCs were detected among 14 of 27 streambed sediment sampling locations. The types and concentrations of OCs in streambed sediment varied by land use. Forest sites had five total detections of three compounds. There were no detections of OCs in streambed sediment at any of the agricultural land use sites. The mixed land use sites had 9 detections of 4 compounds. Twelve of the 13 OCs were found in at least one urban site.

In fish tissues analyzed, 9 OCs were detected among 17 of
24 sites sampled. The types and concentrations of OCs in fish tissue varied by land use. The forest sites had fewer detections than the other land uses. In contrast, agricultural sites had the most types of OCs (eight) detected in fish tissue. At urban sites, seven OCs were detected in fish tissue. OC concentrations in fish tissue tend to increase in a downstream direction on the Mississippi River.

Eight OCs were detected in both fish and streambed sediment samples, they were: cis-chlordane, $o, p$ '-DDD, $p, p^{\prime}$ DDD, $p, p^{\prime}$-DDE, $p, p$-DDT, hexachlorobenzene, transnonachlor, and PCBs. The most frequently detected OCs were $p, p^{\prime}$-DDE, and $p, p^{\prime}$-DDD in streambed sediment and $p, p^{\prime}$-DDE and PCBs in fish tissues. Although no OCs were detected in streambed sediment at agricultural sites, there were 17 detections of organochlorines in fish tissue. Urban streams had concentrations of total DDT and metabolites in streambed sediment that exceed guidelines for classification of sites with high probabilities of adverse effects to aquatic organisms. Total DDT was the only OC within an urban land use that exceeded guidelines for piscivorous wildlife. 


\section{REFERENCES}

Fallon, J.D., Fong, A.L., and Andrews, W.J., 1997, Water-quality assessment of part of the Upper Mississippi River Basin, Minnesota and Wisconsin-Pesticides in streams, streambed sediment, and groundwater, 1974-94: U.S. Geological Survey Water-Resources Investigation Report 97-4141, 53 p.

Foreman, W.T., Connor, B.F., Furlong, E.T., Vaught, D.G., and Merten, L.M., 1995, Methods of analysis by the U.S. Geological Survey National Water Quality Laboratory-Determination of organochlorine pesticides and polychlorinated biphenyls in bottom sediment by dual capillarycolumn gas chromatography with electron-capture detection: U.S. Geological Survey Open-File Report 95-140, 78 p.

Larson, S.J., Capel, P.D., and Majewski, M.S., 1997, Pesticides in surface waters-Distributions, trends and governing factors: Chelsea, Mich., Ann Arbor Press, 373 p.

Lee, K.E., and Anderson, J.P., 1998, Water-quality assessment of the Upper Mississippi River Basin, Minnesota and Wisconsin-Polychlorinated biphenyls in common carp and walleye fillets, 1975-95: U.S. Geological Survey WaterResources Investigation Report 984126, $27 \mathrm{p}$.

Leiker, T. J., Madsen, J. E., Deacon, J.R., Foreman, W.T., 1995, Methods of analysis by the U.S. Geological
Survey National

Water Quality Laboratory-Determination of chlorinated pesticides in aquatic tissue by capillary-column gas chromatography with electron-capture detection: U.S. Geological Survey Open-File Report 94-710, $42 \mathrm{p}$.

Minnesota Department of Health, 1999, Minnesota Fish Consumption Advisory: Division of Environmental Health, St. Paul, Minnesota, $96 \mathrm{p}$.

Newell, A.J., Johnson, D.W., and Allen, L.K., 1987, Niagra River Biota Contamination Project-Fish flesh criteria for piscivorous wildlife: New York State Department of Environmental Conservation, Division of Fish and Wildlife, Bureau of Environmental Protection, Technical Report 87-3, 182 p.

Nowell, L.H., Capel, P.D., and Dileanis, P.D., 1999, Pesticides in stream sediment and aquatic biota-Distribution, trends, and governing factors: Boca Raton, Fla., CRC Press LLC, 1001 p.

Nowell, L.H. and Resek, E.A., 1994, National standards and guidelines for pesticides in water, sediment, and aquatic organisms-Application to water-quality assessments: Rev. Environmental Contaminant Toxicology, v. 140 p. 1-164.

Shelton, L.R. and Capel, P.D., 1994 Guidelines for collecting and processing samples of stream bed sediment for analysis of trace elements and organic contaminants for the National Water-Quality Assessment Program: U.S. Geological Survey Open-File Report 94-458, $20 \mathrm{p}$.

Stark, J.R., Fallon, J.D., Fong, A.L., Goldstein, R.M., Hanson, P.E., Kroening, S.E., and Lee, K.E., 1999, Water-quality assessment of part of the Upper Mississippi River Basin, Minnesota and WisconsinDesign and implementation of water-quality studies, 1995-98: U.S. Geological Survey WaterResources Investigation Report 99$4135,85 \mathrm{p}$.

U.S. Environmental Protection Agency, 1992, National study of chemical residues in fish, Volume II: U.S. Environmental Protection Agency, EPA 823-R-92-008b, variously paged.

1995, Guidance for assessing chemical contaminant data for use in fish advisories, Volume I, Fish sampling and analysis, 2d: Office of Water, EPA 823-R-95-007, September 1995.

1996, Drinking water regulations and health advisories: U.S. Environmental Protection Agency, Office of Water, EPA 822-B-96002, October 1996, 11 p.

-1997 , National sediment quality survey, Volume I. The incidence and severity of sediment contamination in surface waters of the United States: U.S. Environmental Protection Agency, Office of Science and Technology, EPA 823-R-97-006, variously paged. 